\title{
自発的に話しかける対話ロボットの 話しかけの一手法
}

\author{
石井 健太郎 $* 1$ ・沜 康彦 $* 2$ ・Thomas KANOLD $* 2,3$ • 今井 倫太 $* 4$
}

\begin{abstract}
本稿では，自発的に話しかけるロボットの話しかけ手法として，機能紹介対話手法を提案する。機能紹 介対話手法は，ロボットが自身が持つ機能を見てみるか尋ねることにより，情報提供を受ける意図はない が，ロボットが持つ機能を見てみたいと思う人間を対話に引き付けることを狙う手法である。機能紹介対 話手法を実装した案内ロボットを大学の入学センターで運用し，ロボットとの対話ログ・対話後のアンケー トデータを解析した。対話ログの解析から, 通常対話を行うロボットと比較して, 機能紹介対話を行うロ ボットは, より多く案内を開始し，かつ，対話の終了を示す発話を認識した。さらに, アンケートデータ の解析から，機能紹介対話を行うロボットが，自分の活動を邪魔されたという印象を低減していることが 認められた。
\end{abstract}

キーワード：対話ロボット，ヒューマンロボットインタラクション，機能紹介対話

\section{1. はじめに}

近年，人間に対するサービスを人間の代わりに行う インタラクティブロボットが開発されている。特に, 展示場や販売店といった公共の場で動作するインタラ クティブロボットが多く開発されている $[1,2,3]$. 公共の場で動作するインタラクティブロボットは，コ ンピュータに慣れていない人間でもロボットとやり取 りができるよう，人間にとって自然なインタラクショ ン手段である音声対話ができるものが多い。このよう なロボットは，ロボットから自発的に働きかけ，人間 が知り得なかった新しい情報を提供できるという点 で, 従来のコンピュータに比べて幅広い活躍が期待さ れている.

音声対話ロボットの実現のためには, 音声認識・自 然言語解析や音声合成が必要不可欠である。しかし, これらの要素技術を組み合わせただけでは，人間と口 ボットの適切な対話を実現することができない，現在 公共の場で動作するロボットは, ロボットの動作をロ

$\dagger$ A Speaking Technique for Self-Driven Interactive Robot Kentaro ISHII, Yasuhiko HATO, Thomas KANOLD and Michita IMAI

*1 科学技術振興機構 ERATO五十嵐デザインインタフェースプロ ジェクト

Japan Science and Technology Agency, ERATO, IGARASHI Design Interface Project

*2 慶應義塾大学大学院 理工学研究科

Graduate School of Science and Technology, Keio University

*3 Technische Universität Darmstadt

*4 慶應義塾大学 理工学部

Faculty of Science and Technology, Keio University
ボットに詳しい人間に見守られており，対話する人間 はロボットの動作を聞いてからロボットと対話する場 合が多い。例えば, 博物館の展示において, 対話口 ボットの展示に説明員がついていて, 対話の方法を説 明するような場合である。一方, ペットロボットのよ うな家庭用のロボットは, 対話する以前から対話中も 含めて, パッケージや説明書により人間はどのように 対話すればいいかを理解することができる。このよう な場合は, 対話する人間はロボットと適切に対話する ことが容易になる。しかし， ロボットの説明員や説明 書がない状況で対話する場合には, 人間とロボットの 間で行われる対話はより困難になる. Onoらの研究で は, 見ず知らずのロボットが現れて人間に依頼をして も，人間がロボットの発話を理解しにくいことが報告 されている [4]。人間同士の対話でも, 見ず知らずの 人に突然話しかけられたら, 真剣に受け止めない場合 があるのと同じように， ロボットが自発的に人間に働 きかけ，人間の知らない情報を提供しようとしても， 正しく聞いてもらえなければ役割をはたすことができ ない. 将来ロボットが様々な場面で利用される際に は, このように事前の説明なしに対話が行われること が想定されるため, 要素技術だけではなく対話の心理 的な側面から，人間とロボットの対話を考慮する必要 がある。

心理的な側面から，人間とロボットの対話を扱った 研究には以下がある。今井らの研究では, 人間の五感 を利用した発話によって, ロボットの発話を人間が真 剣にとらえるようになることが報告されている [5]. 
塩見らの研究では, あらかじめ人間に取り付けられた 無線タグで対話相手を識別し，相手によって発話内容 を変化させることで, 科学館の来館者の科学技術への 興味が増したことが示されている [6]。また，無線夕 グに関連付けられている相手の名前を呼ぶ行動が, 来 館者に好意的に受け入れられたことも報告されてい る。

これらの研究で明らかにされていない点は, あらか じめロボットと対話することを想定していない状況 で，ロボットからの話しかけによる対話が有効に働く かということである。なぜならば上述の研究は，実験 室実験であるか，フィールド実験であってもロボット と対話することがあることを事前に人間に伝えている 状況での研究である。ロボットが様々な場面，特に公 共の場で利用され，現在人間が果たしている役割を担 うようになった際には，人間はロボットの存在をあら かじめ知らないことも想定される。そのような場合 に，ロボットからの話しかけが有効に働くかを検証す ることが必要である。

本稿では, 人間の活動環境において自ら人間に働き かけるロボットの話しかけ手法として, 機能紹介対話 手法を提案する。機能紹介対話手法では, 話しかけの 際に，情報提供することを伝えるのではなく，自身が 持つ機能を見てみるか尋ねる発話を行う。このことに より，情報提供を受けるつもりはないが，ロボットが 持つ機能を見てみたいと思う人間を対話に引き付ける ことを狙う。ロボットが持つ機能を見てみたいと思う ことの効果は, ロボットが普及するにつれ, 薄まる可 能性があるが，本研究は現時点の有効性の提案と検証 を目的とする.

大学の入学センターに配置されている受付案内口 ボット用いて, 大学の情報を自発的に来場者に提供す るロボットを開発し, 提案手法で話しかけるロボット と，情報提供することを伝えるロボットを比較する フィールド実験を行う。実験の対象となった対話者 は，あらかじめ実験と知らされて集められたのではな く, 自分自身の活動中にロボットに話しかけられて フィールド実験に参加する.

本稿の構成は以下の通りである。2 章では本研究の 背景となるロボットからの話しかけの可能性と課題に ついて述べ, 関連研究との比較をまとめる. 3 章では ロボットの存在をあらかじめ知っているとは限らない 人間に対する話しかけ手法を提案する。4 章では自発 的に情報提供するロボットによる話しかけを比較した フィールド実験について述べる．5章に扔いて実験結 果を考察する。6 章に打いて本稿を結論づける.

\section{2. 背景}

\section{1 ロボットの自発的な話しかけ}

従来のコンピュータと比較したロボットの特長は, 種々のアクチュエータを用いて実世界に働きかけるこ とができるということである。たとえば，アームつき の移動ロボットは，アームを用いて実世界の物体をつ かみ移動させることができる。

対話ロボットにおいてもこの特長が活かされる. 対 話ロボットは自らが持つ移動機構によって, 人間が意 四していなくても自ら近づいていき話しかけることが できる。これはコンピュータに打けるポップアップ広 告が人間がコンピュータを用いて作業していることを 前提としていることと大きく異なる。この特長は, 駅 やショッピングモールのような多くの人が集まる場所 で, 案内や宣伝のためにロボットを利用する動機にな りうる。現在のところ, 安全性・信頼性・費用の問題 から, 実際に自発的に移動し話しかけるロボットの利 用は限られているが, 技術の発達とともに多くの応用 が期待されるロボットの利用法である.

\section{2 本稿で取り組む課題}

2.1節で示した通り，自ら移動できる対話ロボット は案内や宣伝に利用することが期待できる。しかし， 話しかけられる人間が自分の活動をさえぎる話しかけ を受け入れるかはわからない. 佐竹らの実験の結果で は，公共の場で単純に人間のもとに近づき話しかける ロボットが，対話に失敗することが示されている [7].この結果から示されているように, ロボットが 話しかけても多くの人間が自分の活動を優先してロ ボットの働きかけを無視することがあり，この問題を 解決することが自ら案内や宣伝を行うロボットを有効 に利用するために重要である。

本稿では案内や宣伝の場面を想定し, 今井らの研究 $[5] \cdot$ 塩見らの研究 $[6]$ とは異なり, 実験参加者がロ ボットと対話することをあらかじめ想定していない状 況で有効に働く話しかけ手法を提案することを課題と する. 佐竹らの研究[7]では, 自然に発生するヒュー マンロボットインタラクションに焦点を当て, ロボッ トの存在に気づかない人間も実験の対象としており, 本研究と課題を共有しているといえる.

\section{3 関連研究との比較}

ロボットからの自発的な話しかけ手法を提案したも のとして, 翠らの研究[8]・佐竹らの研究[7]が挙げら れる。

翠らの研究では, ロボットからの自発的な話しかけ 
は 2 種類ある。1つは，対話の開始時にユーザを顔画 像認識で識別し，ロボットから名前を呼びかける。も う 1 つは, 対話中にユーザからの発話が一定時間ない 場合に，ロボットから情報推薦を行う。翠らの自発的 な話しかけによる効果は, 既存の手法と比較して, 情 報推薦が受理されやすく，対話が長く継続することで ある．ただし，ユーザはロボットの前にいることが前 提となっており， ロボットと対話することをあらかじ め想定していない状況に打けるロボットの話しかけを 目的とする本研究とは課題が異なる.

佐竹らの研究では, 事前に蓄積された人間の移動軌 跡・速度に基づいた行動予測によって, 話しかけ相手 の選択方法・人間に気づかれやすい移動方法・ノン バーバルな対話意図の表出方法が提案されており，有 効性が示されている。ただし，佐竹らが人間の移動軌 跡・速度に基づく手法を提案しているのに対して, 本 研究は発話の内容に基づく提案であり，手法が異な る。また, 佐竹らの研究が環境にレーザレンジファイ ンダを配置しているのに対して, 本研究ではロボット に搭載されたセンサのみで動作する点も異なる。

\section{3. ロボットからの話しかけ手法}

\section{1 機能紹介対話手法}

本稿で提案する話しかけ手法は「私がごんな機能を 持っているか見てみませんか？」と話しかける手法で ある。この手法を機能紹介対話手法と呼び，この話し かけを機能紹介対話と呼ぶ。例えば大学の紹介を行う ロボットであれば, 通常の話しかけは「大学について 紹介しましょうか？」というものである。しかし，通 常の話しかけでは話しかけられた人間の意図がロボッ 卜の発話内容と一致していなければ対話には応じない ことが予想できるが，そのような人間でもロボットの 機能は見てみたいと思っている人間をロボットとの対 話に引き付けることを狙う（図 1 )。現在のところ，公 共の場所でロボットから自発的に話しかけられること はそれほど多くないため，「機能を見てみませんか？」 と聞かれれば，それに応じる人間が存在することが期 待できる.
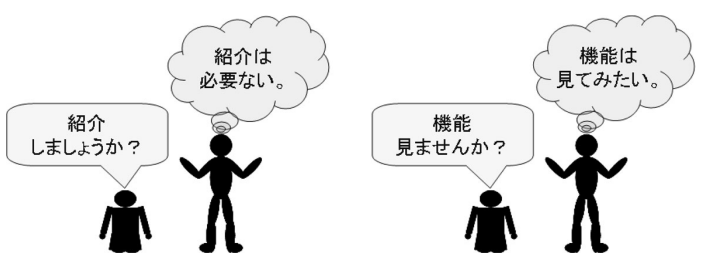

図 1 機能紹介対話手法

\section{2 実装}

本研究では, 受付案内ロボットKEITA [9] 考用い る. KEITAは, 大学の入学センターにおける来訪者 に対する用件の受付と大学の案内を目的として開発さ れた人型ロボットである(図 2 )。

以下に, 機能紹介対話手法を実装したKEITAの動 作手順を示す ${ }^{1}$.

1.レーザレンジファインダで周囲を監視し，移動 物体を検知した場合は体の向きを移動物体に向 ける。

2. カメラにより人間の顔を認識すると, 移動物体 を来訪者と判断し，来訪者に近づく。

3. 来訪者の近くまで到達すると「こんにちは，私 は案内ロボットKEITAです.」と発話し，あい さつと簡易な自己紹介を行う。

4.「私がどんな機能を持っているか見てみません か? 」と来訪者に問いかける.

5. 来訪者が 4 。の問いかけに対して「はい.」と音 声認識した場合は，大学の案内を開始する。問 いかけに対して「いいえ。」音声認識した場 合，または，しばらく問いかけに応じない場合 は，「案内が必要な場合は話しかけてくださ い.」と発話し，元に位置に戻る。

6. 案内コンテンツは来訪者が「はい.」と答える限 り永続的に続き, 案内途中に起こる続きや他の 案内を聞くかの問いかけに対して「もうけっこ うです.」と音声認識した場合, または, しばら く問いかけに応じない場合は，「ありがとうご ざいました。案内が必要な場合は話しかけてく ださい.」と発話し，元の位置に戻る。

太字で示した手順 4 。の発話が，機能紹介対話が 4

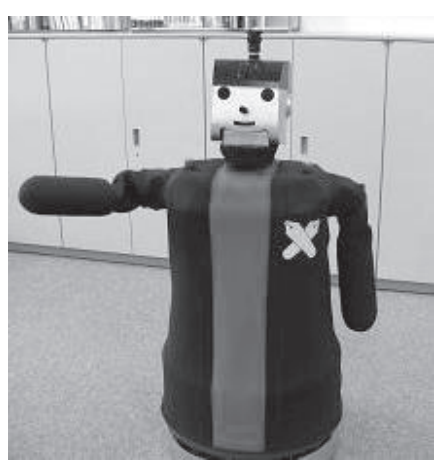

図 2 受付案内ロボットKEITA

1 ここに示した音声認識の語は典型的な例であり，例えば，「は い.」に代わりに「㹉いします。」,「いいえ．」の代わりに 「けっこうです。」といった語も同様に認識される. 
章で比較する通常対話と異なる点である，通常対話の 実装は, 手順 4 。の発話を「大学について紹介しま しょうか? 」に変更したものであり, 来訪者の判定方 法・来訪者に近づく方法・あいさつや自己紹介・案内 を開始する条件・案内の内容はすべて同一である.

\section{4. 実験}

\section{1 実験環境}

機能紹介対話手法の有効性を確かめる実験を, 大学 の入学センターで行った。 入学センターは, キャンパ ス体験イベントや入学試験に関する業務が行われてい る。キャンパス紹介や学部紹介のパンフレットやビデ オが設置されているほか, 過去の入学試験問題を閲覧 することができる，大学・入学試験の資料を求めて来 訪する受験生やその家族が最も多く, 大学見学イベン 卜の打ち合わせのために来訪する大学・高校関係者も 多い.

3.2 節で述べた，機能紹介対話と通常対話を実装し たKEITAを動作させ，機能紹介対話を行った対話者 を実験群とし，通常対話を行った対話者を対照群とし て，KEITAの動作を切り替えながら実験を行った。

実験時の部屋の配置は図 3 の通りである。実験者は 対話者の位置からは見えないように柱の影におり，対 話セッションが終了するまで姿を現さない，対話の様 子は部屋の隅に取り付けられたビデオカメラによって 撮影されている.

\section{2 実験手順}

実験の手順は以下の通りである。

1. 3.2節で述べた条件で来訪者を認識した場合に は，KEITAはバッテリステーションから離れ て人間に話しかける。

人間の認識が失敗した場合には以下の測定には

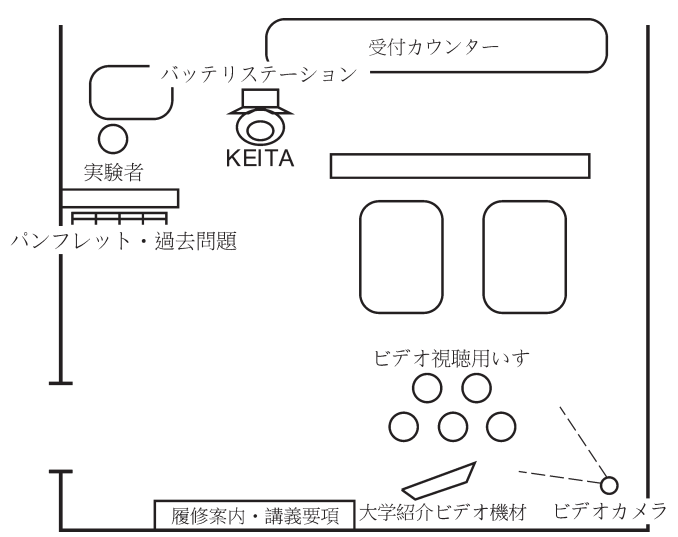

図 3 実験環境
考慮にいれない。

2。対話が終了し, KEITAがバッテリステーショ ンに向かって動き出した時点で, 1つの実験 セッションを終了とする。

3. 実験セッションが終了したら, 直ちに実験者は 対話者にアンケートと映像・画像の利用許諾を 求める。

対話者によっては, アンケート・利用許諾をい ずれかまたは両方断ることがある。

4. KEITAは, バッテリステーションに戻ったら 直ちに移動物体の監視をはじめ, 次の来訪者が 来るまで待機する。

\section{3 収集データ}

実験で収集するデータは以下の 3 つである.

- KEITAの発話と人間の発話の認識結果を記録し た対話ログ

・実験の様子を撮影したビデオ

・対話後に対話者に対して行ったアンケートデータ 対話ログは，KEITAを制御するコンピュータにテ キスト形式で自動的に保存される。対話データはその ときのタイムスタンプとともに記録される。

ビデオは実験期間中録画しており，撮影範囲は KEITAが移動できる範囲をカバーしている。対話 後, 後述のアンケート用紙に時刻と対話者の特徴 (着 ている服の色・性別)を記入することによって, 他の データとビデオデータを対応付けた.

対話後のアンケートでは, 以下の項目を質問した。

・ロボットとの対話経験

ロボットとの対話経験を, ロボットと直接対話し たことがある・ロボットを直接見たことがある・ ロボットをテレビや雑誌で見たことがある・ない の 4 項目から選んでもらった。

- 来訪の目的

対話者が入学センターに来訪した目的を自由記述 で回答してもらった。

・ロボットに興味を持ったか ロボットに興味を持った度合いを 1 〜 5 までの 5 段階尺度で評価してもらった。

・ロボットに邪魔されたと感じたか

ロボットに邪魔されたと感じた度合いを 1 ～ 5 ま での 5 段階尺度で評価してもらった。

\section{4 実験結果}

実験は平日の午前 9 時から午後17時まで， 2 週間に わたって行われた。実験期間中, KEITAは26名の来 訪者に話しかけた(図 4 )。そのうち，15名を実験群と 
して機能紹介対話で動作させ，11名を対照群として通 常対話で動作させた。

実験対象となる 26 名のうち, 19名からアンケート 回答を得た。内訳は, 実験群 8 名・対照群11名であ る.アンケート回答者のすべてが，直接ロボットと対 話するのは初めてであると答えた。この結果から，以 下のアンケートデータについて，ロボットとの対話経 験がデータに与える影響は少ないと考える。

実験対象となる26名のうち, KEITAのことをあら かじめ知っており，KEITAを見ることが目的で来訪 した参加者が 2 名いた。男性・女性それぞれ 1 名の大 学卒業生で，どちらも対照群に含まれていた。2.2節 で示したとおり，本実験の条件はロボットと対話する ことをあらかじめ想定していない人間に対して話しか けが有効に働くかを検証することであるため，この 2 名を以降の解析から除外する。

表 1，2，3 は, 実験参加者の性別・職業・来訪目 的の分布を示したものである。本実験はフィールド実 験であり，実験参加者を統制できなかったため，分布 に偏りがある。いずれの実験参加者もロボットとの対 話とは異なる用事で入学センターに来訪しているが, 分布の偏りについて他の実験結果に基づき考察する必 要がある。

対話ログを解析し, ロボットが大学の案内を開始 し, かつ, 対話の終了を示す発話を認識したかを検証 する。大学の案内の開始は, 3.2 節の動作手順 5 。で 「はい.」と認識した場合にあたり，実験参加者が最初 のロボットの問いかけに応じたことを表す。対話の終 了を示す発話は，3.2節の動作手順 6 . で「もうけっこ うです.」と認識した場合にあたり，ロボットの問いか けに応じて対話を終了したことを表す。

結果は，機能紹介対話では15名中13名であるのに 対して, 通常対話では 9 名中 2 名であった(表 4 ).

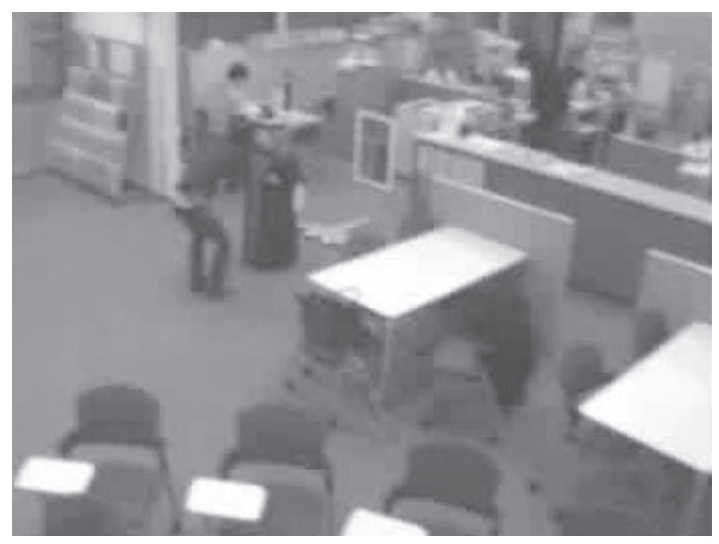

図 4 入学センターでの実験
フィッシャーの正確確率検定で検定し，ロボットが大 学の案内を開始し, かつ, 対話の終了を示す発話を認 識した割合に, 有意差が認められた $(p<0.05)$.

図 5 に興味を持ったか, 図 6 に邪魔と感じたかのア ンケート結果を示す。マン・ホイットニーの $U$ 検定 で検定し，興味を持った度合いには有意差は認められ なかったが, 邪魔と感じた度合いには有意差が認めら れた $(p<0.05)$.

表 1 実験参加者の性別

\begin{tabular}{c|c|c}
\hline & 実験群 & 対照群 \\
\hline 男性 & 10 & 3 \\
女性 & 5 & 6 \\
\hline
\end{tabular}

表 2 実験参加者の職業

\begin{tabular}{l|c|c}
\hline & 実験群 & 対照群 \\
\hline 受験生 & 8 & 1 \\
受験生の保護者 & 3 & 1 \\
大学生 & 0 & 3 \\
大学職員 & 4 & 2 \\
高校関係者 & 0 & 2 \\
\hline
\end{tabular}

表 3 実験参加者の来訪目的

\begin{tabular}{l|c|c}
\hline & 実験群 & 対照群 \\
\hline 入学資料の収集 & 11 & 2 \\
入学センターの催しに参加 & 0 & 3 \\
会議・打ち合わせ & 4 & 4 \\
\hline
\end{tabular}

表 4 大学の案内を開始し, かつ, 対話の終了を示 す発話を認識したか $(p<0.05)$

\begin{tabular}{l|c|c}
\hline & 実験群 & 対照群 \\
\hline 該当 & 13 & 2 \\
該当せず & 2 & 7 \\
\hline
\end{tabular}

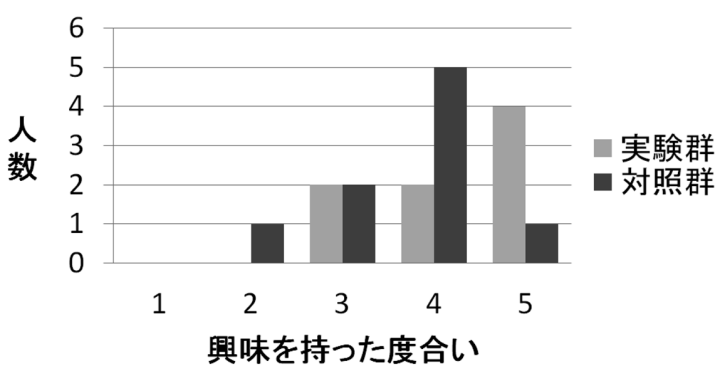

図 5 興味を持ったか(n.s.) 


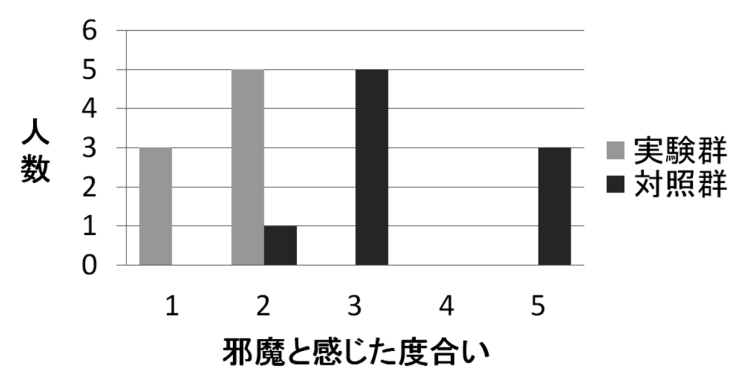

図 6 邪魔と感じたか $(p<0.05)$

\section{5. 考察}

実験で得られた結果は, 最初のロボットの問いかけ に応じ，かつ，対話を終了する発話を行った実験参加 者の割合が，機能紹介対話で話しかけられた場合に高 かった $(p<0.05)$ ことを示している.この条件に該当 する実験参加者は, 対話終了までロボットの問いかけ に応じ続けたことになる。なぜならば，ロボットの問 いかけに応じない場合は, その時点で対話が終了し, 対話の終了を示す発話が認識されないためである.こ のことを考えると, この条件に該当する実験参加者 は, 最初のロボットの問いかけに応じてから対話の終 了を示す発話を行うまで, 大学の案内を聞いていたと 考えられる。したがって, 機能紹介対話手法が, 案内 の達成率を向上させる手段として有効であると考えら れる.

アンケート結果より，ロボットに対して興味を持っ た度合いに有意差は認められなかった。このことよ り, 実験群と対照群の実験参加者の間にロボットに対 する興味の偏りはなく，興味の度合いが実験結果に影 響を与えたとはいえない。

アンケート結果より, 機能紹介対話で話しかけられ た実験参加者は活動を邪魔されたという印象を受けに くい $(p<0.05)$ ことを示している。これは，本質的に 人間の活動に割り込む宣伝ロボットにとって, 実用的 な特長である。

\section{6. まとめ}

本稿では, 自発的に話しかけるロボットの話しかけ 手法として, 機能紹介対話手法を提案した. 機能紹介 対話手法は，ロボットが自身が持つ機能を見てみるか 尋ねることにより, 情報提供を受ける意図はないが, ロボットが持つ機能を見てみたいと思う人間を対話に 引き付けることを狙う手法である。

機能紹介対話手法を実装したロボットを大学の入学 センターで運用し，ロボットとの対話ログ・対話後の
アンケートデータを解析した。対話ログの解析から， 通常対話を行うロボットと比較して, 機能紹介対話を 行うロボットは, より多く大学の案内を開始し, か つ, 対話の終了を示す発話を認識した。ささら, アン ケートデータの解析から, 機能紹介対話を行うロボッ トが，自分の活動を邪魔されたという印象を低減して いることが認められた。

\section{謝辞}

本研究の一部は文部科学省グローバルCOEプログ ラム「環境共生・安全システムデザインの先導拠点」に 依るものであることを記し, 謝意を表す。

\section{参 考 文 献}

［1］宮下善太, 神田崇行, 塩見昌裕, 石黒浩, 萩田紀博, “顧客と顔見知りになるショッピングモール案内口 ボット”, 日本ロボット学会誌, Vol.26, No.7, pp.103$114,2008$.

[2] M.P. Michalowski, S. Sabanovic, C. DiSalvo, D. Busquets, L.M. Hiatt, N.A. Melchior, R. Simmons, "Socially Distibuted Perception : GRACE plays social tag at AAAI 2005," Autonomous Robots, Vol.22, No.4, pp.385-397, 2007.

[ 3 ] M. Shiomi, D. Sakamoto, T. Kanda, C.T. Ishii, H. Ishiguro, and N. Hagita, "A Semiautonomous Communication Robot - Field Trial at a Train Station - ," Proc. of the 3rd ACM/IEEE Intl. Conf. on HumanRobot Interaction, pp.303-310, 2008.

[4] T. Ono and M. Imai, "Reading a Robot's Mind : A Model of Utterance Understanding based on the Theory of Mind Mechanism," Proc. of AAAI Conference on Artificial Intelligence, pp.142-148, 2000.

[5] 今井倫太, 鳴海真里子, “人間の五感を利用した口 ボットとのコミュニケーションへの没入の実現”, 計 測自動制御学会論文集, Vol.42, No.4, pp.342-350, 2006.

［6] 塩見昌裕, 神田崇行, ダニエルイートン, 石黒浩, 萩 田紀博, “RFID タグを用いたコミュニケーションロ ボットによる科学館での展示案内”, 日本ロボット学 会誌, Vol.24, No.4, pp.489-496, 2006.

[ 7 ] 佐竹聡, 神田崇行, Dylan F. Glas, 塩見昌裕, 石黒浩, 萩田紀博, “環境情報を理解してサービス提供を行う ロボットの実現”，インタラクション 2009 論文集, pp.173-180, 2009.

[8] 翠輝久, 河原達也, 正司哲朗, 美濃導彦, “質問応答 情報推薦機能を備えた音声による情報案内システム”, 情報処理学会論文誌, Vol.48, No.12, pp.3602-3611, 2007.

[ 9 ] 村田機械株式会社, “慶應義塾大学入学センターの受 付ロボット『KEITA』について”,

http://www.muratec.net/jp/news/news051025.html (2009年 2 月17日 受付) (2009年 8 月 7 日 採録) 
[問い合わせ先］

干 223-8522 神奈川県横浜市港北区日吉 3- 14- 1

慶應義塾大学大学院 理工学研究科

石井 健太郎

TEL : 045-560-1070

E-mail：kenta@ayu.ics.keio.ac.jp

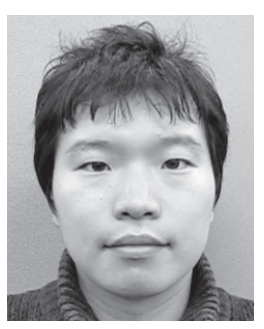

\section{坚并健太蓈 [非会員]}

2003 年慶應義塾大学理工学部情報 工学科卒業. 2005 年同大学大学院理 工学研究科修士課程修了。2009年同 大学大学院理工学研究科博士課程所定 単位取得退学. 現在, 科学技術振興機構 ERATO五十嵐デザインインタフェース プロジェクト技術員。ヒューマンロ ボットインタラクション,ユーザイン タフェース,コンピュータビジョンの 研究に興味を持つ.

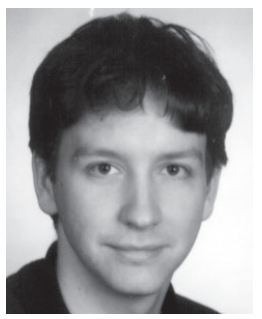

\section{Thomas KANOLD [非会員]}

Thomas Kanold is studying for his Master of Computer Science at the Technische Universität Darmstadt. He was an exchange student at Keio University in 2008 to 2009 .

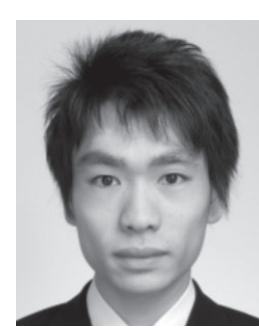

\section{沜康彦 [非会員]}

2008 年慶應義塾大学理工学部情報 工学科卒業. 現在, 同大学大学院開放 環境科学専攻前期博士課程在学中. ヒューマンロボットインタラクション に関する研究に興味を持つ。

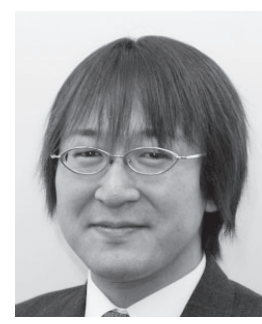

\section{今哭览倫太 [非会員]}

1992 年慶應義塾大学理工学部電気 工学科卒業. 1994 年同大大学院理工 学研究科計算機科学専攻修士課程修 了。同年, NTTヒューマンインタ フェース研究所に入社. 1997 年 ATR 知能映像通信研究所へ出向. 2002 年 慶應義塾大学大学院理工学研究科開放 環境科学専攻博士課程修了. 現在, 慶 應義塾大学理工学部情報工学科准教授 及び,ATR知能ロボティクス研究所客 員研究員. 人型ロボットとのインタラ クションの研究に従事. 電子情報処理 学会, 情報処理学会, 人工知能学会, 日本認知科学会, ヒューマンインタ フェース学会, ACM, IEEE 各会員. 博士 (工学). 


\section{A Speaking Technique for Self - Driven Interactive Robot}

by

\section{Kentaro ISHII, Yasuhiko HATO, Thomas KANOLD and Michita IMAI}

Abstract :

This paper proposes a function introduction interaction, which encourages human-robot interaction on first contact with a self-driven interactive robot. The function introduction interaction aims to cause a person's interest by asking the person to watch the robot's interactive function. We developed a promotion robot and conducted a field experiment to verify effectiveness of the function introduction interaction, and analyzed interaction logs, and questionnaire answers. The results showed that the function introduction interaction enabled the robot to perform its task and decreased the feeling of being interrupted.

Keywords : Interactive Robot, Human- Robot Interaction, Function Introduction Interaction

\section{Contact Address : Kentaro ISHII}

Graduate School of Science and Technology, Keio University

Hiyoshi 3-14-1, Kohoku-ku, Yokohama 223-8522, JAPAN

TEL : 045-560-1070

E-mail : kenta@ayu.ics.keio.ac.jp 